\title{
Performance Evaluation of Commercial Banks Based on Factor Analysis
}

\author{
Qin Lv리 ${ }^{1}$ Yingdong Wang ${ }^{1}$, Dijia Zhang ${ }^{1}$, Muyang Yang ${ }^{1}$, Yueming Zheng ${ }^{1 *}$ \\ ${ }^{1}$ College of Literature Law \& Economics, Wuhan University of Science \& Technology, Wuhan, China
}

\begin{abstract}
China's commercial banks are the main part of the country's financial system and a key link in the national economy. However, because of the late start of commercial banks in China, the performance evaluation system of commercial banks is not perfect. Based on the financial data of 36 listed commercial banks in 2018, this paper uses factor analysis method to evaluate the performance of commercial banks, and analyzes the operating conditions of commercial banks.
\end{abstract}

\section{Introduction}

As the main body of China's financial system, commercial banks have five functions: regulating economy, credit creation, credit intermediary, payment intermediary and financial service. The operating efficiency of the commercial banking system directly affects the health of the whole national economic system and the efficiency of socio-economic resources, which is a crucial part of the national economic system. DEA model (Data Envelopment Analysis) was used to calculate and analyze the comprehensive efficiency of China's 31 listed commercial banks from 2014 to 2017. The results showed that China's commercial banks generally had high operating efficiency and stable development. However, under the backgrounds of the Chinese economic slowdown and the market-based reform of interest rates, the overall operating efficiency of China's commercial banks has shown a declining trend due to the reduced scale efficiency of commercial banks and the impact of the Internet finance industry on commercial banks in the traditional financial industry. The driving force of commercial banks in the new era has changed from factor driven to innovation-driven. Chinese scholars pointed out the shortcomings of Chinese commercial banks' insufficient innovation capacity and slow innovation process. Faced with the current situation that China's banking industry is in urgent need of innovation, the study on the performance evaluation of the banking industry is of great practical significance to promote commercial banks to adjust industrial structure, promote system innovation and improve the utilization efficiency of financial resources.

Performance evaluation of commercial banks refers to the use of a series of indicators and models to reflect the overall operating conditions of commercial banks. The results are crucial for commercial banks to establish strategic development goals, improve operating efficiency and promote the sound development of commercial banks in the market economy. Compared with foreign developed countries, China's commercial banks started late, and the performance evaluation system of commercial banks is not perfect. There are still some defects such as disunified evaluation system, imperfect organizational structure, excessive number of evaluation indicators, and too much emphasis on scale and numerical value, which need to be further improved.

\section{Literture Review}

In recent years, many scholars at home and abroad have conducted in-depth research on the performance evaluation of commercial banks and achieved certain results. $\mathrm{Li}$ [1] et al. formed a GFS algorithm based on the performance evaluation of commercial bank loan projects by using grey correlation analysis method, fuzzy evaluation synthesis method and stepwise discriminant analysis method, providing a new idea for the performance evaluation of commercial bank loan project. Jiang [2] applied the KMV model to the pricing and performance evaluation of commercial banks and conducted empirical analysis to make the results more comprehensive, authentic and accurate. Based on the heterogeneity of commercial banks, Liu [3] et al. added two assessment dimensions of robustness and sustainability to the three basic dimensions of profitability, operational ability and innovation ability of commercial banks in the past, and reconstructed the comprehensive operational performance evaluation system of commercial banks. Fang [4] theoretically combined the Promethee method with the construction of the performance evaluation model of commercial banks, and the specific application still needed to be tested in practice. Mohammad [5] used the DEA model based on network relaxation measure (SBM) to evaluate

*Corresponding author's e-mail: wenfaxueyuan18@163.com 
the performance of commercial banks, overcoming the defect that the previous standard DEA model often ignored the internal structure of bank performance. Jelena [6] used the analytic hierarchy process (AHP) in the multivariate decision analysis method to evaluate bank performance, and proved the feasibility of the method through empirical research. This paper aims to evaluate the performance of China's listed commercial banks in 2018 by using factor analysis based on the existing research results, so as to provide a new reference for the regulation of China's commercial banking system.

\section{Methods}

\subsection{Description of Data and Variables}

By February 2020, there have been 36 listed commercial Banks on Shanghai Stock Exchange and the Shenzhen Stock Exchange, including Industrial and Commercial Bank of China, China Merchants Bank, China Citic Bank and Bank of Shanghai. In order to conduct scientific and reasonable performance evaluation for commercial banks, this paper selected the financial data of these 36 commercial Banks in 2018 for analysis, and from the four dimensions of growth ability, profitability, debt ability and indicators of per share, we selected nine financial indicators, such as the year-on-year growth rate of net profit, net profit on sales, asset-liability ratio and earnings per share, see TABLE I.

TABLE I. FINANCIAL INDICATORS OF PERFormance EVALUATION

\begin{tabular}{|c|c|c|}
\hline $\begin{array}{l}\text { First grade } \\
\text { indicators }\end{array}$ & $\begin{array}{l}\text { Second grade } \\
\text { indicators }\end{array}$ & Calculation formula \\
\hline \multirow{2}{*}{$\begin{array}{l}\text { Growth } \\
\text { ability }\end{array}$} & $\begin{array}{l}\text { Year-on-year } \\
\text { growth rate of } \\
\text { net profit }\end{array}$ & $\begin{array}{l}\text { (Net profit of current } \\
\text { period - Net profit of } \\
\text { last period)/Net } \\
\text { profit of last period }\end{array}$ \\
\hline & $\begin{array}{l}\text { Year-on-year } \\
\text { growth rate of } \\
\text { total revenue }\end{array}$ & $\begin{array}{l}\text { (Current operating } \\
\text { income - Last } \\
\text { operating } \\
\text { income)/Last } \\
\text { operating income }\end{array}$ \\
\hline \multirow{2}{*}{ Profitability } & $\begin{array}{l}\text { Net profit on } \\
\text { sales }\end{array}$ & Net profit/Sales \\
\hline & $\begin{array}{l}\text { Return on } \\
\text { equity }\end{array}$ & Net profit/Net assets \\
\hline \multirow{2}{*}{$\begin{array}{l}\text { Debt } \\
\text { capacity }\end{array}$} & $\begin{array}{l}\text { Asset-liability } \\
\text { ratio }\end{array}$ & $\begin{array}{l}\text { Total liabilities/Total } \\
\text { assets }\end{array}$ \\
\hline & Equity ratio & $\begin{array}{l}\text { Total } \\
\text { liabilities/Owners } \\
\text { equity }\end{array}$ \\
\hline Indicators & Earnings per & After-tax \\
\hline
\end{tabular}

\begin{tabular}{l|l|l}
\hline of per share & share & $\begin{array}{l}\text { profit/Total common } \\
\text { stock }\end{array}$ \\
\cline { 2 - 3 } & $\begin{array}{l}\text { Net assets per } \\
\text { share }\end{array}$ & $\begin{array}{l}\text { Total shareholder } \\
\text { equity/Common } \\
\text { stock }\end{array}$ \\
\cline { 2 - 3 } & $\begin{array}{l}\text { Operating cash } \\
\text { flow per share }\end{array}$ & $\begin{array}{l}\text { operating flow from } \\
\text { activities/Total } \\
\text { common stock }\end{array}$ \\
\hline
\end{tabular}

\subsection{Modeling}

In this paper, through the method of factor analysis, a large number of financial indicators were reduced and information was concentrated on generate fewer independent factors, and these factors could represent most of the information of the original financial indicators. In order to demonstrate the mathematical model of factor analysis, there were $p$ variables, and each variable had been standardized. Then the original variable was divided into $k(k<p)$ factors $f_{1}, f_{2}, f_{3} \ldots f k$.

$$
\left\{\begin{array}{l}
x_{1}=a_{11} f_{1}+a_{12} f_{2}+a_{13} f_{3}+\cdots+a_{1 k} f_{k}+\varepsilon_{1} \\
x_{2}=a_{21} f_{1}+a_{22} f_{2}+a_{23} f_{3}+\cdots+a_{2 k} f_{k}+\varepsilon_{2} \\
x_{3}=a_{31} f_{1}+a_{32} f_{2}+a_{33} f_{3}+\cdots+a_{3 k} f_{k}+\varepsilon_{3} \\
\cdots \\
x_{p}=a_{p 1} f_{1}+a_{p 2} f_{2}+a_{p 3} f_{3}+\cdots+a_{p k} f_{k}+\varepsilon_{p}
\end{array}\right.
$$

The premise of factor analysis was that there was a strong correlation between the original variables. Correlation Coefficient Matrix, anti-image Correlation Matrix and Bartlett Test of Sphericity were used to Test the Correlation of the original variables. The Bartlett Test of Sphericity was used in this article, $\mathrm{P}<0.001$, so factor analysis was possible.

\subsection{Factor Extraction}

In this paper, Principal Component Analysis (PCA) was used to extract factors, and factors with eigenvalues greater than 1 are selected. Table II showed the commonality of the original variables, that was, the common factor variance ratio, indicating the degree to which the information of each original variable was retained after extraction by Principal Component Analysis. It could be concluded that, except for the slightly lower extraction rate of operating cash flow per share, the other 8 variables all had a higher degree of commonality, and the degree of information loss of each variable was lower. Therefore, the overall effect of factor extraction was better.

TABLE II. COMMON FACTOR VARIANCES

\begin{tabular}{l|l|l}
\hline & Initial & Extraction \\
\hline $\begin{array}{l}\text { Year-on-year } \\
\text { growth rate of net } \\
\text { profit }\end{array}$ & 1.000 & 0.886
\end{tabular}




\begin{tabular}{l|l|l}
\hline $\begin{array}{l}\text { Year-on-year } \\
\text { growth rate of total } \\
\text { revenue }\end{array}$ & 1.000 & 0.872 \\
\hline Net profit on sales & 1.000 & 0.845 \\
\hline Return on equity & 1.000 & 0.843 \\
\hline Asset-liability ratio & 1.000 & 0.957 \\
\hline Equity ratio & 1.000 & 0.964 \\
\hline Earnings per share & 1.000 & 0.940 \\
\hline Net assets per share & 1.000 & 0.872 \\
\hline $\begin{array}{l}\text { Operating cash flow } \\
\text { per share }\end{array}$ & 1.000 & 0.625 \\
\hline
\end{tabular}

Extraction Method: Principal Component Analysis.

\subsection{Factor Rotation}

It could be known that the eigenvalues of components 1 , 2, 3 and 4 were all greater than 1, and they could explain the variance of $86.702 \%$, so they were selected as the main components. Since the new variables obtained directly by Principal Component Analysis had no definite practical significance, the factor loading matrix was rotated in an orthogonal way by means of Varimax with Kaiser Normalization, so that the factor could be interpreted.

TABLE III. ROTATED COMPONENT MATRIX

\begin{tabular}{l|l|l|l|l}
\hline \multirow{2}{*}{$\begin{array}{l}\text { Original } \\
\text { Indicators }\end{array}$} & \multicolumn{4}{l}{ Component } \\
\cline { 2 - 5 } $\begin{array}{l}\text { Net assets per } \\
\text { share }\end{array}$ & 0.909 & -0.037 & 0.210 & 0.012 \\
\hline $\begin{array}{l}\text { Earnings per } \\
\text { share }\end{array}$ & 0.889 & 0.048 & 0.381 & 0.043 \\
\hline $\begin{array}{l}\text { Operating cash } \\
\text { flow per share }\end{array}$ & -0.778 & -0.009 & 0.045 & 0.131 \\
\hline $\begin{array}{l}\text { Equity ratio } \\
\begin{array}{l}\text { Asset-liability } \\
\text { ratio }\end{array}\end{array}$ & 0.008 & 0.981 & -0.015 & 0.020 \\
\hline
\end{tabular}

\begin{tabular}{l|l|l|l|l}
\hline $\begin{array}{l}\text { Net profit on } \\
\text { sales }\end{array}$ & 0.100 & -0.094 & 0.909 & -0.030 \\
\hline Return on equity & 0.411 & 0.331 & 0.751 & 0.030 \\
\hline $\begin{array}{l}\text { Year-on-year } \\
\text { growth rate of } \\
\text { total revenue }\end{array}$ & -0.162 & -0.179 & -0.320 & 0.843 \\
$\begin{array}{l}\text { Year-on-year } \\
\text { growth rate of } \\
\text { net profit }\end{array}$ & 0.069 & 0.289 & 0.359 & 0.817 \\
\hline
\end{tabular}

Rotation converged in 6 iterations.

Table IV showed the rotated component matrix. The larger the load coefficient in the load matrix was, the stronger the comprehensive indicators could interpret the corresponding original indicators. In the first component, the coefficient between net assets per share and earnings per share was relatively large, which could be interpreted as the factor of indicators per share, representing the present value of assets and earnings per share of commercial banks. In the second component, the coefficient of equity ratio and asset-liability ratio was quite large, which could be interpreted as the liability capacity factor. In the third component, the coefficient of net profit on sales and return on equity was higher, which could be explained as the profitability factor. In the fourth component, the coefficient of year-on-year growth rate of operating revenue and year-on-year growth rate of net profit was relatively large, which could be interpreted as growth capacity factor.

\subsection{Factor Score}

After the four factors were determined, we needed to calculate the specific value of each commercial bank in each factor, namely the factor score. In order to effectively evaluate the performance of commercial banks, the comprehensive scores of four factors were set as $F 1, F 2, F 3$ and $F 4$, and the comprehensive scores of commercial banks' performance could be calculated through (2).

Scores $=(27.024 \% * F 1+23.863 \% * F 2+20.237 \% * F 3$

$+15.577 \% * F 4) / 86.702 \%$

TABLE IV. FACTOR SCORE AND RANKING

\begin{tabular}{|c|c|c|c|c|c|c|c|c|c|c|}
\hline \multirow{2}{*}{ Commercial Banks } & \multicolumn{8}{|c|}{ Factor's score and ranking } & \multicolumn{2}{|c|}{$\begin{array}{l}\text { Combined score } \\
\text { and ranking }\end{array}$} \\
\hline & $F 1$ & Ranking & $F 2$ & Ranking & F3 & Ranking & F4 & Ranking & $F$ & Ranking \\
\hline Bank of Ningbo & 1.25 & 5 & 0.24 & 14 & 1.57 & 2 & 1.23 & 5 & 1.04 & 1 \\
\hline Bank of Guiyang & 1.70 & 3 & 0.44 & 10 & 1.54 & 3 & -0.65 & 25 & 0.89 & 2 \\
\hline China Industrial Bank & 3.05 & 1 & 0.02 & 18 & -0.16 & 20 & -0.27 & 19 & 0.87 & 3 \\
\hline China Merchants Bank & 2.12 & 2 & -0.64 & 29 & 0.82 & 10 & 0.97 & 8 & 0.85 & 4 \\
\hline Bank of Changsha & 0.84 & 8 & 1.60 & 2 & 0.13 & 15 & 0.50 & 12 & 0.82 & 5 \\
\hline Bank of Chengdu & -0.11 & 14 & 1.06 & 8 & 1.25 & 6 & 1.46 & 3 & 0.81 & 6 \\
\hline
\end{tabular}




\begin{tabular}{|c|c|c|c|c|c|c|c|c|c|c|}
\hline Bank of Nanjing & -0.89 & 31 & 1.17 & 6 & 2.00 & 1 & 0.28 & 14 & 0.56 & 7 \\
\hline Bank of Shanghai & 0.43 & 10 & -1.02 & 32 & 0.84 & 9 & 2.51 & 1 & 0.50 & 8 \\
\hline Bank of Hangzhou & -0.40 & 18 & 1.18 & 4 & -0.19 & 21 & 1.63 & 2 & 0.45 & 9 \\
\hline $\begin{array}{l}\text { Postal Savings Bank of } \\
\text { China }\end{array}$ & -0.51 & 22 & 3.01 & 1 & -1.80 & 35 & 0.17 & 17 & 0.28 & 10 \\
\hline Bank of Jiangsu & 0.11 & 12 & 1.08 & 7 & 0.33 & 13 & -0.84 & 28 & 0.26 & 11 \\
\hline China Zheshang Bank & -0.20 & 16 & 1.37 & 3 & -0.63 & 28 & -0.61 & 24 & 0.06 & 12 \\
\hline $\begin{array}{l}\text { Shanghai Pudong } \\
\text { Development Bank }\end{array}$ & 1.66 & 4 & -0.43 & 22 & -0.32 & 22 & -1.50 & 36 & 0.05 & 13 \\
\hline $\begin{array}{l}\text { Qingdao Rural } \\
\text { Commercial Bank }\end{array}$ & -0.91 & 32 & 0.25 & 12 & 0.10 & 17 & 1.06 & 7 & 0.00 & 14 \\
\hline Ping An Bank & 1.02 & 7 & 0.47 & 9 & -1.72 & 34 & -0.37 & 20 & -0.02 & 15 \\
\hline $\begin{array}{l}\text { Changshu Rural } \\
\text { Commercial Bank }\end{array}$ & -0.56 & 24 & -0.30 & 20 & -0.11 & 19 & 1.26 & 4 & -0.06 & 16 \\
\hline $\begin{array}{l}\text { Zijin Rural Commercial } \\
\text { Bank }\end{array}$ & -1.08 & 35 & 1.17 & 5 & -0.39 & 24 & 0.22 & 16 & -0.07 & 17 \\
\hline Huaxia Bank & 1.08 & 6 & -0.63 & 28 & -0.55 & 26 & -0.68 & 26 & -0.09 & 18 \\
\hline China Minsheng Bank & 0.59 & 9 & 0.25 & 13 & -0.55 & 27 & -1.30 & 33 & -0.11 & 19 \\
\hline Bank of Xi'an & -0.71 & 29 & -0.93 & 31 & 0.85 & 8 & 0.67 & 11 & -0.16 & 20 \\
\hline $\begin{array}{l}\text { Wuxi Rural } \\
\text { Commercial Bank }\end{array}$ & -0.66 & 27 & 0.23 & 15 & -0.01 & 18 & -0.14 & 18 & -0.17 & 21 \\
\hline China Everbright Bank & -0.69 & 28 & 0.02 & 17 & -0.34 & 23 & 0.24 & 15 & -0.25 & 22 \\
\hline $\begin{array}{l}\text { Bank of } \\
\text { Communications }\end{array}$ & -0.52 & 23 & -0.01 & 19 & 0.19 & 14 & -0.89 & 29 & -0.28 & 23 \\
\hline $\begin{array}{l}\text { Agricultural Bank of } \\
\text { China }\end{array}$ & -0.96 & 33 & 0.09 & 16 & 0.47 & 12 & -0.74 & 27 & -0.30 & 24 \\
\hline Bank of Beijing & -0.59 & 25 & -0.53 & 25 & 0.53 & 11 & -0.50 & 23 & -0.30 & 25 \\
\hline $\begin{array}{l}\text { Chongqing Rural } \\
\text { Commercial Bank }\end{array}$ & 0.08 & 13 & -0.43 & 21 & 0.11 & 16 & -1.33 & 34 & -0.30 & 26 \\
\hline China Citic Bank & -0.40 & 19 & 0.27 & 11 & -0.51 & 25 & -1.09 & 31 & -0.37 & 27 \\
\hline Bank of Suzhou & -0.15 & 15 & -0.50 & 24 & -0.71 & 29 & -0.46 & 22 & -0.43 & 28 \\
\hline $\begin{array}{l}\text { Industrial and } \\
\text { Commercial Bank of } \\
\text { China }\end{array}$ & -0.98 & 34 & -0.92 & 30 & 1.29 & 5 & -1.10 & 32 & -0.45 & 29 \\
\hline $\begin{array}{l}\text { China Constuction } \\
\text { Bank }\end{array}$ & -0.76 & 30 & -1.41 & 33 & 1.39 & 4 & -1.00 & 30 & -0.48 & 30 \\
\hline Bank of Zhengzhou & -0.44 & 21 & -0.46 & 23 & -0.72 & 30 & -0.41 & 21 & -0.51 & 31 \\
\hline Jiangsu Rural Bank & -0.61 & 26 & -0.62 & 27 & -0.98 & 31 & 0.34 & 13 & -0.53 & 32 \\
\hline Bank of China & -1.21 & 36 & -0.57 & 26 & 0.91 & 7 & -1.38 & 35 & -0.57 & 33 \\
\hline $\begin{array}{l}\text { Zhangjiagang Rural } \\
\text { Commercial Bank }\end{array}$ & -0.43 & 20 & -1.44 & 34 & -1.15 & 32 & 0.85 & 9 & -0.65 & 34 \\
\hline $\begin{array}{l}\text { Jiangyin Rural } \\
\text { Commercial Bank }\end{array}$ & 0.12 & 11 & -1.56 & 36 & -1.85 & 36 & 0.77 & 10 & -0.69 & 35 \\
\hline Bank of Qingdao & -0.27 & 17 & -1.53 & 35 & -1.64 & 33 & 1.12 & 6 & -0.69 & 36 \\
\hline
\end{tabular}




\section{Conclusions}

After analysis, the following conclusions can be drawn:

From the index factor per share, the top three are China Industrial Bank, China Merchants Bank and Bank of Guiyang. And China Industrial Bank's debt profitability and growth capacity are all slightly below average, making it a mere third in the overall score. China Merchants Bank ranks third because of its poor debt capacity. Bank of China and Zijin Rural Commercial Bank rank the worst in terms of per-share indicator factors, but Zijin Rural Commercial Bank's debt capacity is among the highest, making it in the middle of the overall ranking. In terms of debt capacity, the top three banks are Postal Savings Bank of China, Bank of Changsha and China Zheshang Bank. At the bottom of the list are Zhangjiagang Rural Commercial Bank, Jiangyin Rural Commercial Bank and Bank of Qingdao, reflecting a poor ability to use external capital. In terms of profitability, Bank of Nanjing, Bank of Ningbo and Bank of Guiyang are in the top three spots, while the present asset value per share and the profit of the Bank of Nanjing are not high. The lowest-ranked in this list is the Jiangyin Rural Commercial Bank. In terms of growth capacity, Bank of Shanghai, Bank of Hangzhou, Bank of Chengdu and Bank of Changshu perform best, while Bank of China and Shanghai Pudong Development Bank perform worst. According to the comprehensive scores after giving weights to every factor, the top five are Bank of Ningbo, Bank of Guiyang, China Industrial Bank, China Merchants Bank, Bank of Changsha. Except the Bank of Ningbo, the other four listed commercial banks are all in unbalanced development. For example, although the Index factor per share and profitability of the Bank of Ningbo give outstanding performance, but it lacks adequate growth capacity; China Industrial Bank ranks first on index factor per share, but its other capabilities are slightly below the average level. Zhangjiagang Rural Commercial Bank, Jiangyin Rural Commercial Bank, and Bank of Qingdao are lowest-ranked in this list, but their growth capacity was above average.

Since the reform and opening up, China's commercial banks have made rapid development. The supervision system and evaluation system of commercial banks have been developed from scratch and improved day by day. International competitiveness and international influence have also been significantly improved. In recent years, China's economic growth has slowed down, China's commercial banks have lost the momentum of development. Through the performance evaluation of factor analysis on 36 listed commercial banks in China in 2018, it is found that the development of Chinese commercial banks is unbalanced in all aspects, and the evaluation results provide a reference for improving the regulatory system of commercial banks and promoting the reform of commercial banks.

\section{Acknowledgment}

Special thanks to the teachers of Wuhan University of Science \& Technology for their support. We would also like to thank the innovation and entrepreneurship training program for Chinese college students and the innovation and entrepreneurship fund for graduate students of Wuhan University of Science \& Technology. Project number 201910488002X and JCX201958.

\section{References}

1. J. X. Li, F. Hu and Z. H. Liu, "A new loan project performance evaluation model of the commerical bank," Journal of Hunan University. Natural science, vol. 37, pp. 83-87, 2010.

2. T. H. Jiang, "Loan pricing and performance evaluation of commercial bank," Journal of Wuhan University of Technology, vol. 31, pp. 155-160, 2009.

3. J. M. Liu and J. R. Zhang, "Reconstruction and measurement of the comprehensive business performance evaluation system of Chinese commercial Banks -- based on the analysis of industry heterogeneity," Journal of Changchun University of Science and Technology, vol. 32, pp. 70-75, 2019.

4. X. Fang, "Using PROMETHEE in the bank's performance measurement," Collected Essays on Finance and Economics, vol. 01, pp. 28-32, 2006.

5. Z. M. Mohammad, E. Ali, "Comprehensive performance evaluation of banking branches: A three-stage slacks-based measure (SBM) data envelopment analysis," International Review of Economics and Finance, pp. 359-376, 2019.

6. S. Jelena and M. Evelina, "The evaluation of bank performance using a multicriteria decision making model: a case study on Lithuanian commercial banks," Technological and Economic Development of Economy, vol. 18, pp. 189-205, 2012. 